\title{
CHARACTERIZATION OF THE ESSENCE OF THE HUMAN PHYSICAL CAPITAL CONCEPT IN RELATION TO THE FITNESS INDUSTRY
}

\author{
Aleksandra Cuprika \\ Latvian Academy of Sport Education, Latvia \\ Andra Fernate \\ Latvian Academy of Sport Education, Latvia \\ Leonids Cupriks \\ Latvian Academy of Sport Education, Latvia
}

\begin{abstract}
A large part of the society perceives the body as a fundamental tool to advance in social life, as a capital in labour relations and in sexual relations as well. The possibility to transform one's own physical capital into economic, social or cultural capital, which is an opportunity a person receives through carrying out physical activity, is also a value in the field of fitness which is an industry that is worth billions. That is why the aim of this study was to investigate in-depth characterization of the nature of the physical capital concept, linking it to the field of fitness. The study is based on 48 literature sources and scientific articles, 2 of which are in Latvian, 5 in Russian and 41 - in English. The essence of the content of the physical capital concept has been investigated and the connections of notions in different theoretical contexts has been evaluated, starting from the beginning of the physical capital concept. The definitions were grouped in a broader and narrower scope. In the narrower sense, physical capital is a person's skills and abilities - innate or acquired over time-, which help to perform a specific physical work, move, strengthen or improve physical health and capacity for work. In the broader sense - as values and investments in the body, building of a body in society. In the broader sense of physical capital, the main goal is its transformation into other forms of capital in order to obtain additional benefits or a new status in the society.
\end{abstract}

Keywords: fitness, human capital, physical capital.

\section{Introduction}

Usually people associate the word capital with richness, wealth and property. Capital is a beneficial asset that includes material and physical resources. Not only can capital be accumulated, converted into cash and reproduced, but it can also be created as new added value (Menšikovs, 2009; Samuelson \& Nordhaus, 2004).

For most people, capital is associated only with a bank account, real estate, number of cars and other means that affect their lives. These assets are easy to count, measure, compare - they create differences between people; they can be 
exchanged, sold, invested for additional benefits; they can be controlled. However, there are other, sometimes invisible forms of capital which affect a person's life and its quality. For example, nowadays the body is like an active and capital in the society, perceived as a symbol of difference, an emblem, as evidence of control, work and struggle to achieve a good form; a fashion icon, a brand that favours those who have it; a reward for those who put in effort and are able to achieve a more „civilized” physique (Bourdieu, 1988).

A large part of the society perceives the body as a fundamental tool to advance in social life, as a capital in labour relations and in sexual relations as well. Physical capital is the attitude towards the body, the value of body change, ways of interpreting the body and investments in it (Hutson, 2012), which differentiates people in different social environments.

Belonging to a particular social group influences the opportunities and desires a person has to create or transform his or her capital. The possibility to transform one's own physical capital into economic, social or cultural capital, which is an opportunity a person receives through carrying out physical activity, is also a value in the field of fitness which is an industry that is worth billions. By investing in one's body, a person is able to contribute to the growth of physical capital, which, in turn, enables one to increase the sense of belonging to a particular social group and further improve the process of promoting physical capital as a result of increasing social belonging.

That is why the aim of this study was to investigate in-depth characterization of the nature of the physical capital concept, linking it to the field of fitness.

The study is based on 48 literature sources and scientific articles, two of which are in Latvia, 5 in Russian and 41 - in English. The essence of the content of the physical capital concept has been investigated and the connections of notions in different theoretical contexts has been evaluated, starting from the beginning of the physical capital concept. The definitions were grouped in a broader and narrower scope.

\section{Review of Literature and Discussion}

When evaluating forms of capital and the processes of their accumulation from a societal point of view, one can say that a person is formed in a society and accumulates capital through direct interaction with other individuals (Bourdieu, 1986; Shilling, 1991; Hutson, 2012). Due to the fact that a person belongs to a specific part of society, it is possible to improve, use, change, transform one type of capital into another (Radaev, 2010), also influencing the development of society.

In the transformation of capital, French sociologist Pierre Bourdieu distinguishes between three forms of capital - economic, cultural and social. 
Economic capital is the form of capital that affects other capitals and its source is investment. Economic capital is automatically converted to cash value and invested in property. People differ not only by economic capital, but also as a result of the impact of social and cultural capital.

Cultural capital can take three forms:

1) in the form of corporeity, as an indicator of physical capital, which Pierre Bourdieu does not distinguish as a separate form of capital, but adds to the cultural capital as values of body, appearance, style changes and the process of self-improvement, which are obtained as a result from the interaction between mind and the body;

2) in the form of cultural goods, such as books, paintings, dictionaries, diplomas, awards, instruments, etc.;

3) in an institutional way, such as educational institutions, workplaces, places of residence, etc. (Bourdieu, 1986).

Cultural capital focuses on the abilities, skills and knowledge that a person has acquired through belonging to a specific group, which facilitates communication with people who do not know each other but belong to this group; which allows one to recognize a person from a similar social class, status; which automatically brings people together. Cultural capital can, under certain circumstances, be converted into economic capital and invested in the value of education.

Social capital is an element of human relationships that enables more productive action. This capital has the significant benefits that are given to an individual, a family or a group by better contacts (Zìverte, Austers, \& Zilinska, 2003). Social capital is formed through social relationships (connections) and can be converted into economic capital and, under certain circumstances, invested in obtaining a new status (Bourdieu, 1986) (see fig.1).

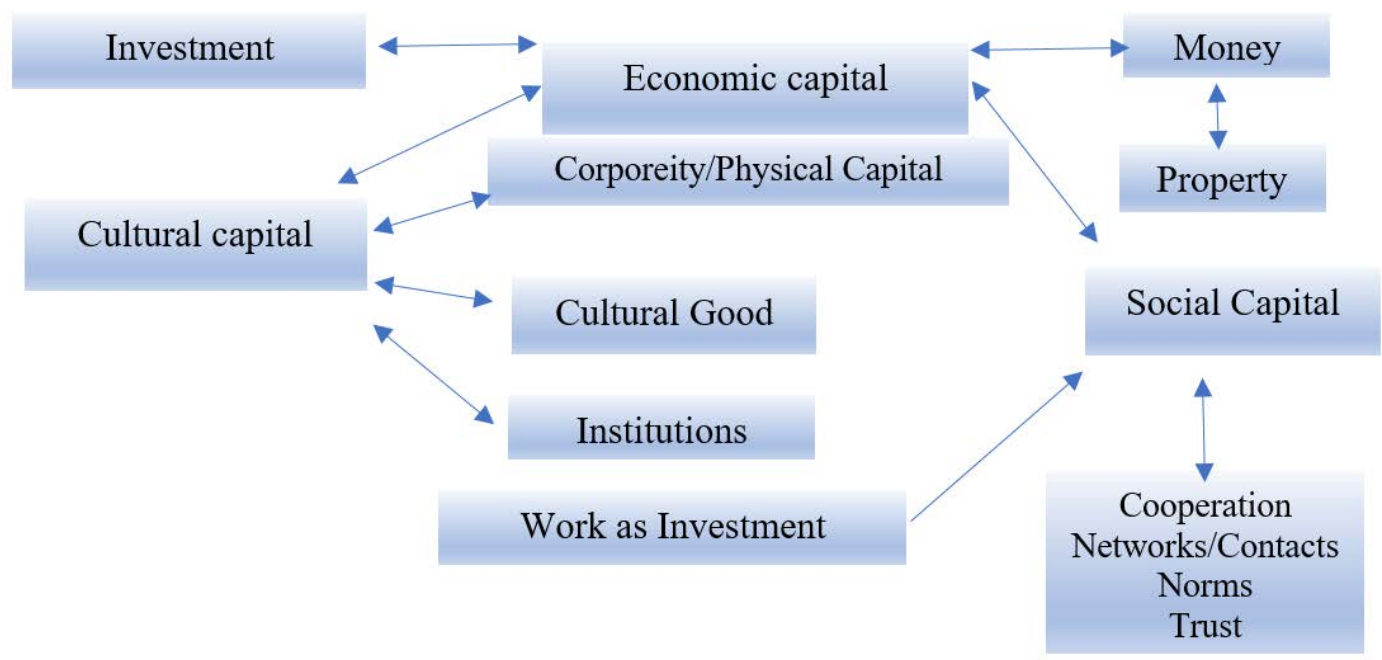

Figure 1 Transformation of Capitals (source: Bourdieu, 1986) 
The abovementioned capital is the ability of people to work together in groups and organizations to achieve common goals (Fukuyama, 1996); it refers to features of social organizations such as trust, norms and cooperation networks (Bourdieu, 1986), which can improve the productivity of the society, facilitating coordinated action (Putnam, 1993). This capital is friends, colleagues and more general contacts, which provide an opportunity to use the economic, cultural and physical capital (Burt, 1992), and which are able to provide individual benefit through involvement in social networks and other social structures (Portes, 1998). Social capital arises through the interaction of individuals, as well as groups or organizations. Like other forms of capital, social capital too grows and accumulates by investing work (creating relationships, paying attention, etc.). This capital can generate public good, it helps to accumulate other forms of capital, which is its social function and value (Coleman, 1988). James S. Coleman states that one of the problems in building social capital is that the individual has to invest work to create it, but the fruits of this type of capital are primarily enjoyed by a group, a community, so the individual has little motivation to invest in it (Coleman, 1988).

Based on the theory of capital transformation by Pierre Bourdieu, it can be concluded that economic capital is the capital that influences other forms of capital. Economic capital depends on investments, and vice versa: the higher the economic capital, the higher the investment that is automatically converted into money, which is invested in property or elsewhere. Economic capital affects cultural capital, which is made up of corporeity, cultural goods and institutions, but cultural capital also affects economic capital, which can be transformed and thus funds can be acquired. The greater the economic capital, the more opportunities to invest it in cultural capital, and vice versa: by investing work in increasing cultural capital, the individual is able to influence their own economic capital.

Economic capital also affects social capital, and vice versa. Under the influence of social capital, networks, contacts, norms in the society and trust is formed, which, using social capital, can be transformed into economic capital and converted into cash.

Cultural capital and social capital are also interlinked. Using the components of social capital, it is possible to transform cultural capital into economic, and vice versa: through cultural capital, it is possible to obtain components of social capital such as networks, contacts, etc. Based on the above, it can be concluded that capitals are interdependent: by increasing one of them, it is possible to increase the others, but all of it is based on work as an investment. When analysing Pierre Bourdieu's theory of capitals, one can see that capital transformation requires a society which brings additional benefits. 
When evaluating capital in context with a person, it can be concluded that, by developing in a society, a person also benefits the society, organization, family, culture and other groups the person interacts with when the person has the opportunity and the desire to. A person's education, health improvement procedures, developing qualification, purchase of stylist and hairdresser services are also investments in capital, which improve and develop the person. A person cannot be separated from his or her capital, because it is impossible to deprive a person of their knowledge, health or appearance, it cannot be lost, so it also forms the capital of the particular person. By investing in human capital, organizations can also lose their investment in an employee if the employee leaves (Radaev, 2010), not gaining any public benefit from the particular individual. However, if a person wants to exchange human capital for money and invest for profit, society is needed (Becker, 1975).

Some researchers believe that human capital encompasses several forms of capital, which affects the particular person and investment in them, for example, physical capital (physical health and healthy behaviour), emotional capital (psychological and mental health), individual capital (the person's character, value system, etc.), social capital (benefits of communication in a group obtained by the person), intellectual capital (level of knowledge, cognitive abilities), financial capital (ability to earn money, etc.) (see fig.2) (Bailey, Shawn, \& Albert, 2013).

All these forms of capital are interlinked. By investing in one of them, it is possible to raise another one, and vice versa: reducing one can worsen a component of the human capital.

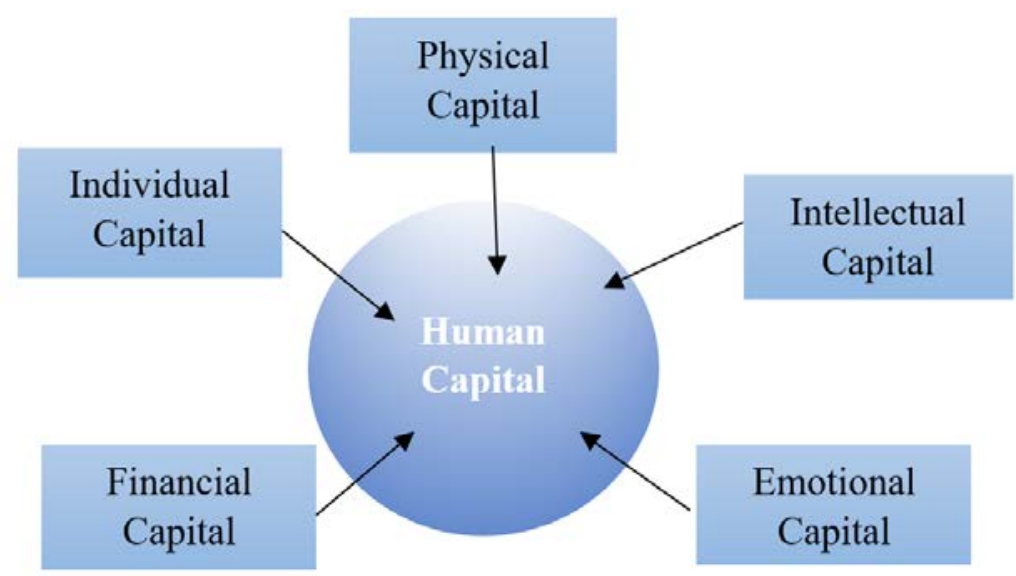

Figure 2 Components of Human Capital (source: Bailey et al., 2013)

This study focuses on a person who is developing in a society, based on Pierre Bourdieu's theory of capitals, analysing physical capital and its promotion as a form of a separate capital. The term physical capital refers to the economy; 
it refers to the physical assets that are in a company or organization. It is not easy to understand its significance in relation to phenomena related to a person and their body.

In sociological theories, for many years the body has been the main subject of scientific interest. The essence of body development has begun from improving physical form and shaping to a socializing agent that can provide multiple benefits to the owner in the process of capital accumulation and transformation.

The inclusion of physical capital in cultural capital has created several limitations in the study of the body in the field of sociology, and several researchers, including those analysed in this study, have distinguished it in their works as a separate form of capital (Shilling, 2003; 2005; Hutson, 2012; Čuprika, Fernāte, \& Čupriks, 2015), thus enabling a better understanding of physical capital promotion and transformation into other capitals.

A number of researchers have studied physical capital based on Pierre Bourdieu's theory of capitals, naming it differently, for example, body capital (Black, 2004; Mears \& Finlay, 2005), sexuality capital (Martin \& Matt, 2006), erotic capital (Green, 2008), gender capital (Bridges, 2009). Based on the above, the question arises as to why there are so many interpretations of Pierre Bourdieu's theory and why the body has become such an important structure. This study is based on the idea that physical capital is a broader concept, which serves as an umbrella term and includes other forms of capital related to the body. Based on Pierre Bourdieu's theory, David Hutson distinguishes physical capital as a separate form of capital, which includes such components as eroticism, sexuality, beauty and power.

The body and the capitals associated with it play an important role in everyday life - they help to include or exclude a person in social groups, as well as enable the formation of new social contacts.

Since 1970, understanding of the status of the body has evolved from the assumption that the body is simply there to a great deal of excitement and interest in it. One of the first researchers to start talking about the body as a social concept is Marcel Mauss. He writes about how such body movements as walking and sitting are mastered and how they differ in various social groups (Mauss, 1979). Mary Douglas has studied the relationship between body and society, describing how the body is interpreted and understood in society (Douglas, 1966; 1970). Based on works by M. Douglas, it can be concluded that the physical experience of the body, its appearance and public opinion about it strengthens the group differences (Douglas, 1970).

Further understanding of the body in the social sciences has been influenced by three important researches. The main interest of Michel Foucault has been to historically determine the connection between the body and knowledge and power (Foucault, 1978; 1979). M. Foucault has shown how, through knowledge and 
power, the body is manipulated, taught and created by various technologies to transform it into an „obedient body” (Foucault, 1978).

The main idea of Maurice Merleau-Ponty was that with our body we understand the whole world and what is going on in it and every individual is a psychologically historical structure (Merleau-Ponty, 1962).

In turn, Pierre Bourdieu (Bourdieu, 1978; 1984) sees the body and the process of its development as a form of existence and expression of power. In other words, he believes that actions, diets, taste, aesthetic desires depend on habits that differ in various social classes. Different classes develop different bodies.

Pierre Bourdieu writes that physical capital is the capital that a person accumulates through active participation in the particular society, while being in a set social class, which develops through the interaction between the individual, society, the person's habits and taste (Bourdieu, 1986). This capital is never fully accumulated, it is constantly influenced by the economic, cultural and social processes, in which the body is located (Bourdieu, 1986). Pierre Bourdieu understands a social class as an objective system of classification, where the relation should not be with an individual or class as a part of society or a group of individuals, but with the habits of the particular class (Bourdieu, 1977). Pierre Bourdieu see a habit as an activity, or more precisely, as practice - not what is regularly repeated, taught, but what the person can do spontaneously, invent, improvise, based on the experience acquired, strategically and independently making a decision in order to gain benefit (Bourdieu, 1990a; 1990b; Bourdieu \& Wacquant, 1992). This also sorts people into different social classes. A class is a group of social agents, which has the same conditions of social existence, interests, social experience, value system and who think of themselves as belonging to a particular group of agents (Laberge \& Kay, 2002). Using conceptions of a specific class, incl. habits, Pierre Bourdieu describes how belonging to a class affects imagination (Bourdieu, 1978; 1996; Light, 2005). Attitude towards one's body, acquisition of habits and lifestyle distinguishes the lower social class from the upper one. Since childhood, representatives of the upper social class pay more attention to beauty, diet, health, they form their bodies for others - the society, becoming similar to the norms and models of behaviour accepted in their class (Bourdieu, 1978; Laberage \& Kay, 2002).

The relationship between social class and attitude towards the body can be seen in the results of Pierre Bourdieu's work in 1976, where he reveals the importance of body value, beauty and beauty treatment in the lives of French women: how much attention women from various social classes pay to their selfimage and what do they expect to receive back from it; what are they willing to invest to make a symbolic return on it (Bourdieu, 1996). 
Some researchers, such as Chris Shilling, criticize Pierre Bourdieu's theory, saying that it focuses too much on the environment in which a person is born. However, a closer analysis of Pierre Bourdieu's work (1996) suggests that he describes people's habits as structures that may depend on belonging to a group of agents and that can be changed over the course of life.

A number of scientists have found that a healthy lifestyle movement is a movement of the middle class of society, where through engagement (in physical activity and health prophylactic events) people are able to use their bodies as a means of achieving success (Bourdieu, 1996; Featherstone, 1982; Shilling, 2003; 2004).

An individual's body represents their social and cultural capital. Thus, it can be concluded that the growth of physical capital gives a person the opportunity to change the class of society or to become a member of the desired social group.

Sport and physical activity provide an opportunity to build one's own body, while thinking about others, about the society, and this is called integrating the body into social relationships (Laberge \& Kay, 2002). Hence, the amount of physical activity is a person's visible expression of creating additional social values (physical capital) in order to gain moral virtue and recognition.

The body and its capital are capable of giving more than just appearance. Pierre Bourdieu's work is based on the social-cultural approach, which is based on the link between social inequality, components of capital and attitude towards health and the body. In his understanding, the body is what is called physical capital. The main concept of Pierre Bourdieu's theory is the symbolic value of the body (1978) and the role of the body in gender diversity, society and the reproduction of social inequality (Light, 2005).

In the analysis of Pierre Bourdieu's theory, David Hutson (2012) emphasizes that nowadays fitness coaches represent the overlap between different social classes, using the body as a source of values and earning money with it. Fitness coaches come from a variety of social classes, but most of them have trained, slender, muscular bodies that many people from higher social classes dream of. The boundary between Pierre Bourdieu's depicted „muscular body of a male from the lowest social class”, „beautiful body of a female from the upper class” and „healthy ideal body of the middle class” is currently blurred. Fitness combines the wishes of people from different social classes. Fitness coaches, even those from lower social classes, create and dictate the body ideals that they sell to people from upper social classes in the form of their knowledge. In essence, coaches work not only with the human body, creating it, but also with people's needs, interests and values, demonstrating their body as a value, as the desirable result - thus, they dictate to the higher social classes what an ideal body is.

Nowadays, in the age of plastic surgery, when it is possible to change the body shape, gender, height, skin colour, etc., Pierre Bourdieu's theory of 
corporeality in the reproduction of class inequality is limited. However, given that the taste for the ideal body is synthesizing nowadays, it is important that the way of promoting physical capital, opportunities and aim to engage in physical activity and create the ideal body, is also very different to the representatives of the same social class, which is why social class should not be taken into account. David Hutson (2012) takes into account the environment and social group in which the individual is located when defining physical capital as ,the value of body change in a given social environment, the use of the body as an investment in the body, ways of body interpretation, which can be changed, used, reinvested to obtain additional benefits, opportunities or status in a social group”.

The term physical capital is used to refer to the external and internal components of the body, which in the social-cultural approach help to transform physical capital into other capitals. Shape, size, use of the body (walking, sitting, participating in social life) is highly dependent on the components of the social culture (Bourdieu, 1986).

When selecting definitions for the study, it was taken into account that the nature of physical capital is explained in a broader and narrower sense. In the narrower sense, physical capital is like skills and abilities - innate or acquired over time -, which help a person to perform a particular physical job, move, strengthen or improve physical health and capacity for work. In the broader sense - as values and investments in the body, the formation of the body in a society with the aim of transforming them into other forms of capital.

The term physical capital is described by the essence of a person, physical ability and appearance as an attitude towards one's health, which shows the knowledge and morals of each person (Hutson, 2013; Jutel \& Buetow, 2007; Hamermesh, 2011). Physical capital - investments aimed at building, maintaining and improving a person's health and work capacity (Ilinskij, 1996). P. Bourdieu (1986) believes that the role of physical capital is a strong and healthy body that can be transformed from physical capital into economic, social and cultural capital. K. Shilling defines physical capital as building the body through sport, leisure physical activity, entertainment and other social activities (1991). The body, by its very nature, makes up the concept of absent presence, which can be explained by the fact that the body is visible to all but it cannot be fully analysed (Shilling, 1991); it provides a person with additional uncontrollable advantages or opportunities in the society.

Some authors describe physical capital as a person's skills and abilities, for example, they believe that every person at a certain point in their lives has a set of psychophysiological skills and abilities that make up the person's physical capital (Semenov, 2006, 2009), or that physical capital is a level of physical ability that helps to carry out a particular job and the creator of the state of health of the population (Vinogradov, 1958); physical capital is a person's attribute that can be 
enhanced through the process of physical education and body care (Radaev, 2010).

According to researchers, it can be concluded that physical capital consists of innate and capital acquired over time (Vinogradov, 1958), it is genetically determined and biologically innate (Radaev, 2010). When a person is born, physical capital varies, but over time it can be changed, acquired, improved or also reduced, in other words - influenced.

Considering physical capital in the broader sense, the main goal is its transformation into other forms of capital in order to obtain additional benefits or a new status in society. This can be done in the social group to which the individual belongs.

To better understand the broader meaning of the term physical capital, it is necessary to understand why and how people, for example, professional athletes or models, use their bodies to gain material value and participate in the economic chain. Physical capital is used on a daily basis through the use of one's body. The transformation of physical capital into economic, social or cultural capital can also be viewed as a process whereby the individual gains some sort of benefit due to their body and its external and internal components, for example, finds a life partner (McIrvin Abu-Laban \& McDaniel, 1995). However, the transformation of physical capital depends on the social environment in which a person is situated (Bourdieu, 1985). For instance, a person may have the potential to become a model or a professional athlete, but unless the person knows the right people and is in the right place, the person is unable to transform their physical capital into other capitals and obtain any benefit from it.

Based on the definition developed by David Hutson (2012), physical capital accumulates through interactions in the society and is transformed into other forms of capital, gaining additional benefits or a new status in a society that has its own needs, interests and values. Society partly determines how a person develops his or her physical capital and what the person wants or can gain from it.

Nowadays, most people are constantly transforming their body through exercise, diets, plastic surgery, pharmacy, cosmetics and other means in order to bring themselves closer to the ideals set in the society and to belong in the particular social environment, in order to obtain an additional change value for their body. Over the centuries people thought that their bodies did not belong to them, but now people believe that the body is the central object of existence and attachment. 
SOCIETY. INTEGRATION. EDUCATION

Proceedings of the International Scientific Conference. Volume VI, May $22^{\text {th }}-23^{\text {th }}, 2020.158-170$

\section{Conclusions}

When selecting definitions for the study, it can be concluded that the essence of physical capital in a human related context is interpreted in a broader and narrower sense. In the narrower sense, physical capital is a person's skills and abilities - innate or acquired over time -, which help to perform a specific physical work, move, strengthen or improve physical health and capacity for work. In the broader sense - as values and investments in the body, building of a body in society.

In the broader sense of physical capital, the main goal is its transformation into other forms of capital in order to obtain additional benefits or a new status in the society. This can be done in the social group to which the individual belongs.

By investing in our body, making the decision on the correct interpretation of the body in various social groups, according to the needs and norms of the group, we are able to change, use and reinvest our physical capital to gain additional benefits and opportunities from society and to transform it into other forms of capital.

\section{References}

Bailey, C.H., Shawn, A., \& Albert, P. (2013). Physical activity: an underestimated investment in human capital? Journal of Physical Activity and Health, 10, 289- 308.

Becker, G.S.bb (1975). Human capital: A theoretical and empirical analysis, with special reference to education. $2^{\text {nd }}$ Ed. New York: Columbia University Press for NBER.

Black, P. (2004). The Beauty Industry: Gender, Culture, Pleasure. New York: Routledge.

Bourdieu, P. (1977). Outline of a Theory of Practice. Cambridge: Cambridge University Press.

Bourdieu, P. (1978). Sport and social class. Social Science Information, 17(6), 819-840.

Bourdieu, P. (1984). Distinction: A social critique of the judgment of taste. Trans. R. Nice. Cambridge, MA: Harvard University Press.

Bourdieu, P. (1986). The forms of capital. Handbook of Theory and Research for the Sociology of Education. J. G. Richardson (Ed.). New York: Greenwood Press, 241-258.

Bourdieu, P. (1988). Homo Academicus. Stanford University Press. Retrieved from http://monoskop.org/File:Pierre_Bourdieu_Homo_Academicus_1988.pdf

Bourdieu, P. (1990a). In other words: Essays Toward a reflexive sociology. Stanford, CA: Stanford University Press.

Bourdieu, P. (1990b). The logic of practice. Stanford, CA: Stanford University Press.

Bourdieu, P. (1996). The state nobility: Elite schools in the field of power. Trans. L.C. Clough. Stanford: Stanford University Press.

Bourdieu, P., \& Wacquant, L.J.D. (1992). An invitation to reflexive sociology. Chicago: University of Chicago Press.

Bridges, T.S. (2009). Gender Capital and Male Bodybuilders. Body \& Society, 15(1), 83-107. Burt, R. (1992). Structural Holes. Cambridge, MA: Harvard University Press.

Coleman, J.S. (1988). Social capital in the creation of human capital. The American Journal of Sociology, 94, 95-120. 
Čuprika, A., Fernāte, A., \& Čupriks, L. (2015). Relationship between physical activity and the objective indicators of physical capital for women in fitness. LASE Journal of Sport Science, 6(1), 23-38.

Douglas, M. (1966). Purity and Danger: An Analysis of Concepts of Pollution and Taboo. London, New York: Routledge.

Douglas, M. (1970). Natural Symbols: Explorations in Cosmology. London: Barrie \& Rockliff. Featherstone, M. (1982). The body in consumer culture. Theory, Culture and Society, 1, 18-33. Foucault, M. (1978). The history of sexuality. Volume 1. New York: Vintage Press.

Foucault, M. (1979). Dicipline and punish. New York: Vintage Press.

Fukuyama, F. (1996). Trust: The social virtues and the creation of prosperity. New York: Free Press Paperbacks.

Green, A.I. (2008). The social organization of desire: the sexual fields approach. Sociological Theory, 26(1), 25-50.

Hamermesh, D.S. (2011). Beauty pays: Why attractive people are more successful. Princeton, NJ: Princeton University Press.

Hutson, D. (2012). Training bodies, building status: Health, physical capital, and the negotiation of difference in the U.S. Fitness Industry. [Unpublished Dissertation.]. University of Michigan.

Hutson, D. (2013). Your body is your business card: Bodily capital and health authority in the fitness industry. Social Science \& Medicine, 90, 63-71.

Ilinskij, I. (1996). Investicii v budushhee: obrazovanie $v$ innovacionnom vosproizvodstve. Sankt-Puterburg: Izd. SPbUJeF.

Jutel, A., \& Buetow, S. (2007). A picture of health? Unmasking the role of appearance in health. Perspectives in Biology and Medicine, 50, 421-434.

Laberge, S., \& Kay, J. (2002). The 'new' corporate habitus in adventure racing. International Review for the Sociology of Sport, 37(1), 17-36.

Light, R. (2005). The body, Bourdieu and research on physical education and sport in schools. International Sport Studies, 27(2), 21-38.

Martin, J.L., \& Matt, G. (2006). Theories of Sexual Stratification: Toward an analytics of the sexual field and a theory of sexual capital. Sociological Theory, 24(2), 107-132.

Mauss, M. (1979). Sociology and Psychology: Essays. Trans. B. Brewster. London: Routledge and Kegan Paul.

McIrvin Abu-Laban, S., \& McDaniel, S.A. (1995). Beauty, status and aging. In Feminist issues: Race, class and sexuality (97-122), N. Mandel (Ed.). Scarborough, ON: Prentice Hall Canada Inc.

Mears, A., \& Finlay, W. (2005). Not just a paper doll: How models manage bodily capital and why they perform emotional labor. Journal of Contemporary Ethnography, 34(3), 317-343.

Meņšikovs, V. (2009). Kopkapitāls un jaunatnes dzīves stratēgijas: sociologiiskais aspekts. Sociālo Zinātñu Vēstnesis, 2(9), 7-37.

Merleau-Ponty, M. (1962). Phenomenology of Perception. Trans. C. Smith. London: Routledge and Kegan Paul.

Portes, A. (1998). Social capital: Its origins and applications in modern sociology. Annual Review of Sociology, 24(1), 1-24.

Putnam, R.D. (1993). The Prosperous community: Social capital and public life. The American Prospect, 13(4), 35-42.

Radaev, V. (2010). Ponjatie kapitala. Formy kapitalov i ih konvertacija. Jekonomicheskaja sociologija, 3(4), 22-29. 
Samuelson, P.A., \& Nordhaus, W.D. (2004). Economics. $18^{\text {th }}$ Ed. New York: McGraw-Hill.

Semenov, I. (2006). Psihologicheskie i social'nye aspekty razvitija chelovecheskogo kapitala i modernizacija vnutrifirmennogo obrazovanija. Chelovek kak kapital: novyj jetap upravlenija chelovecheskimi resursami: Pervaja Rossijskaja Mezhbankovskaja konferencija. Moskva.

Semenov, I. (2009). Chelovecheskij i social'nyj kapital: mezhdisciplinarnye i refleksivnopsihologicheskie aspekty vzaimodejstvija. Modernizacija jekonomiki i globalizacija. Pod red. E. Jasina. T. 2. Moskva: Izd. Dom GU VShJe, 434-441.

Shilling, C. (1991). Educating the body: Physical capital and the production of social inequalities. Sociology, 25(4), 653-672.

Shilling, C. (2003). The Body and Social Theory. Published in association with Theory, Culture \& Society. London: Sage Publications.

Shilling, C. (2004). Physical capital and situated action: A new direction for corporeal sociology. British Journal of Sociology of Education, 25(4), 473-487.

Shilling, C. (2005). The Body in Culture, Technology and Society. London: Sage Publications. Vinogradov, M. (1958). Fiziologija trudovyh processov. Leningrad: LGU.

Zīverte, L., Austers, I., \& Zilinska, D. (2003). Sabiedriskie tīkli kā drošumspējas faktors. Cilvēkdroš̄iba, 82-97. 